\title{
The glucocorticoid receptor in recipient cells keeps cytokine secretion in acute graft-versus-host disease at bay
}

\author{
Tina Baake ${ }^{1}$, Katharina Jörß ${ }^{1}$, Jennifer Suennemann ${ }^{1}$, Laura Roßmann ${ }^{1}$, Hanibal \\ Bohnenberger $^{2}$, Jan P. Tuckermann ${ }^{3}$, Holger M. Reichardt ${ }^{1, *}$, Henrike J. Fischer ${ }^{1,4, *}$ \\ and Sybille D. Reichardt ${ }^{1, *}$

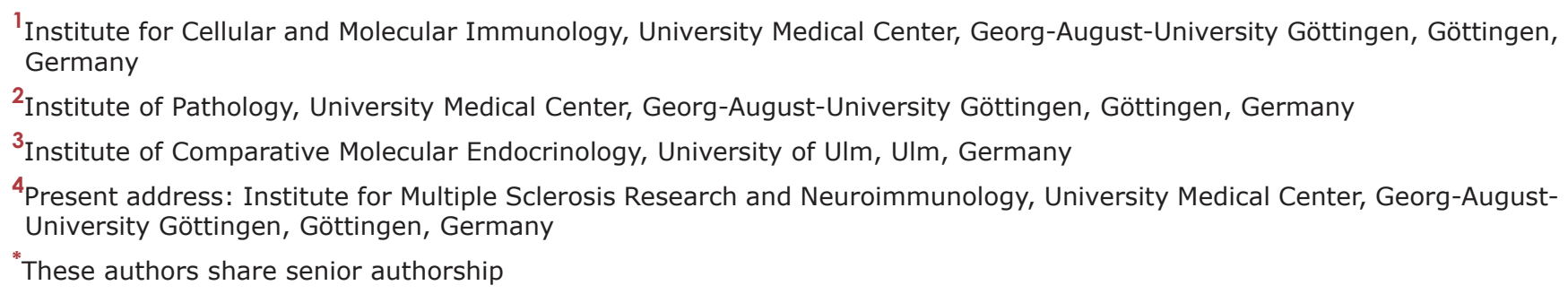

Correspondence to: Holger M. Reichardt, email: hreichardt@med.uni-goettingen.de

Keywords: glucocorticoid receptor; myeloid cells; GvHD; IL-6; cytokine storm

Received: September 01, 2017 Accepted: February 24, 2018 Epub: March 02, 2018 Published: March 20, 2018

Copyright: Baake et al. This is an open-access article distributed under the terms of the Creative Commons Attribution License 3.0 (CC BY 3.0), which permits unrestricted use, distribution, and reproduction in any medium, provided the original author and source are credited.

\section{ABSTRACT}

Graft-versus-host disease (GvHD) is a life-threatening complication of hematopoietic stem cell transplantation (HSCT), which is caused by allogeneic T cells recognizing molecules of the recipient as foreign. Endogenous glucocorticoids (GC) released from the adrenal gland are crucial in regulating such inflammatory diseases. Here we demonstrate that genetically engineered mice, that are largely unresponsive to GC, suffer from aggravated clinical symptoms and increased mortality after HSCT, effects that could be tempered by neutralization of IL-6. Interestingly, selective ablation of the GC receptor (GR) in recipient myeloid cells resulted in fulminant disease as well. While histopathological analysis of the jejunum failed to reveal any differences between sick mice of both genotypes, systemic IL-6 and TNFa secretion was strongly increased in transplanted mice lacking the GR in myeloid cells briefly before the majority of them succumbed to the disease. Collectively, our findings reveal an important role of the GR in recipient cells in limiting the cytokine storm caused by GvHD induction.

\section{INTRODUCTION}

GvHD is a severe inflammatory disease responsible for affliction and mortality in a majority of patients undergoing allogeneic HSCT, a treatment indicated for perilous hematological disorders involving the transfer of hematopoietic stem cells from a healthy donor into a preconditioned patient $[1,2]$. In the first phase of GvHD, local inflammation caused by the conditioning regimen leads to the release of pro-inflammatory cytokines, which activate recipient antigen presenting cells (APC) [3]. Damage to the intestinal epithelium further results in the translocation of pathogen-associated molecules, thereby initiating an innate immune response [4]. In the second phase, T cells in the graft recognize molecules of the recipient as foreign, mostly unmatched MHC class I and II molecules but also polymorphic proteins, and subsequently start to proliferate and differentiate into effector cells [5]. In the final phase of the pathogenic cascade, cytokines and cytotoxic molecules are released by $\mathrm{T}$ cells and myeloid cells, which results in tissue damage in the intestine, liver and skin [1]. This process is generally observed within 100 days post transplant, characterized by symptoms such as erythroderma, diarrhea and jaundice, and referred to as acute GvHD (aGvHD). In contrast, chronic GvHD usually starts later and represents a distinct disease entity that involves systemic fibrosis and autoantibody production [6]. 
Despite considerable research efforts, treatment options for aGvHD remain unsatisfactory and reliable prognostic factors are scarce $[7,8]$. As of yet, systemic GC administration is the only proven first-line therapy for aGvHD. If disease fails to ameliorate after treatment or in the case that GC are not tolerated, second-line therapy can be accomplished by using monoclonal antibodies that target key pathogenic molecules expressed by $\mathrm{T}$ cells such as CD25, CD52 or TNF $\alpha$ [8]. Since none of these agents is sufficiently powerful, continuation of GC treatment is recommended even after onset of second-line therapy. GC therefore remain essential in the management of aGvHD despite the complications that accompany their clinical use, including poor response rates and different adverse effects $[9,10]$. Hence a better understanding of the mode of GC action in aGvHD is important.

Recipient myeloid cells play crucial roles in aGvHD. On the one hand allogeneic immune responses can be initiated by different host APC, and on the other hand mediators are released by macrophages of the host that contribute to tissue damage in target organs [3]. It is thus conceivable that the immunomodulatory activity of GC also involves effects on recipient macrophages, which can be polarized into distinct phenotypes [11]. Following classical activation, they assume a pro-inflammatory phenotype characterized by TNF $\alpha$, IL- $1 \beta$ and IL- 6 release and increased expression of costimulatory and MHC molecules [12]. In contrast, macrophages exposed to GC assume an anti-inflammatory phenotype characterized by markedly reduced cytokine secretion, diminished antigen presentation and increased phagocytosis. GC achieve these effects mostly by modulating gene expression, which either requires binding of the GR to regulatory genomic elements or its interaction with transcription factors such as NF- $\kappa \mathrm{B}$ [13]. Eventually, GC hereby manage to keep inflammation in check, dampen $\mathrm{T}$ cell responses and initiate tissue repair, all of which contributes to their beneficial effects in the control of aGvHD.

Genetic mouse models have considerably helped us to understand the pathophysiological role of the GR in inflammatory diseases and their treatment. Ablating the GR in individual cell types such as myeloid cells (GR ${ }^{\text {lysM }}$ ) [14] or ubiquitously disrupting its dimerization interface $\left(\mathrm{GR}^{\mathrm{dim}}\right)$ [15] allowed to define the cellular targets of GC and their mode of action in mouse models of contact dermatitis, multiple sclerosis, sepsis, rheumatoid arthritis, acute lung injury, and allergic asthma [14, 16-20]. Animal models have also proven to be valuable in the analysis of aGvHD [21]. Experiments in mice for instance showed that adhesion molecules and chemokines in the intestinal tract are crucial targets of $\mathrm{GC}$, and provided evidence that the functionality of CMV-specific T cells in aGvHD can be retained by selectively inactivating the GR $[22,23]$. Studies from our group further revealed that the GR in transplanted $\mathrm{T}$ cells is essential to control disease severity in two mouse models of aGvHD, in particular by repressing the activity of $\mathrm{CD} 8^{+}$cytotoxic $\mathrm{T}$ cells [24]. In this study we tested the role of the GR in radioresistant cells of HSCT recipients, in particular macrophages, and found that endogenous GC keep cytokine secretion during aGvHD at bay. This finding suggests that selectively targeting GC to myeloid cells might offer a new strategy to interfere with aGvHD in affected patients.

\section{RESULTS}

\section{Proper control of aGvHD requires an intact GR in recipient cells}

We previously found that the GR in transplanted $\mathrm{T}$ cells was required to prevent fulminant aGvHD after allogeneic HSCT in mice [24]. Here we set out to explore the importance of the GR in recipient cells. Since mice with an ubiquitous deletion of the GR are not viable [25], we used GR ${ }^{\mathrm{dim}}$ mice which express a GR with a defective dimerization interface [15] and are largely unresponsive to GC [26]. When we transferred bone marrow (BM) and mature $\mathrm{T}$ cells from wildtype $\mathrm{C} 57 \mathrm{BL} / 6$ mice into irradiated $\mathrm{GR}^{\mathrm{wt}} \mathrm{Balb} / \mathrm{c}$ recipients, mice died between day 10 and 30 post transplant (Figure 1A). In contrast, HSCT into $\mathrm{GR}^{\mathrm{dim}}$ mice resulted in exacerbated aGvHD, and the majority of animals died within the first 10 days (Figure 1A). The body temperature of mice with aGvHD was reduced on day 6 , briefly before the peak of the disease [24, 27], and this effect was more pronounced in transplanted $\mathrm{GR}^{\mathrm{dim}}$ than GR $^{\mathrm{wt}}$ mice (Figure 1B). Furthermore, IL-6 and IFN $\gamma$ serum levels on day 6 were significantly more increased in $\mathrm{GR}^{\mathrm{dim}}$ than $\mathrm{GR}^{\mathrm{wt}}$ mice, which is in line with the aggravated clinical symptoms of mutant mice (Figure 1C, 1D). We conclude that an intact GR in recipient cells is required to prevent fulminant disease and early lethality after allogeneic HSCT.

\section{Systemic IL-6 release impacts the severity of aGvHD}

As previous studies provided evidence for an involvement of IL-6 in aGvHD [28, 29], we tested whether the elevated systemic secretion of this cytokine in GR ${ }^{\mathrm{dim}}$ mice might be responsible for the devastating disease course in the mutants. To this end, GR ${ }^{\mathrm{wt}}$ and $\mathrm{GR}^{\mathrm{dim}}$ mice were treated with a neutralizing anti-IL- 6 antibody on day 2 and 6 post transplant followed by monitoring the survival over 42 days. Another cohort of mice was sacrificed on day 6 after only one injection with the antibody and used for analysis. It turned out that the anti-IL-6 antibody therapy of $\mathrm{GR}^{\mathrm{dim}}$ mice prevented early lethality, significantly reduced clinical scores and interfered with the drop in body temperature (Figure 2A-2C). The enhanced systemic IL-6 secretion in GR ${ }^{\mathrm{dim}}$ mice as compared to $\mathrm{GR}^{\mathrm{wt}}$ mice was no longer observed after antibody therapy as expected, whereas IFN $\gamma$ levels in the 
mutants remained high (Figure 2D, 2E). It is noteworthy that anti-IL-6 treatment of GR ${ }^{\mathrm{wt}}$ mice had only a marginal effect on mortality, disease severity and cytokine levels, which failed statistical significance (Figure 2A-2E). In summary, our data suggest that impaired GR function in recipient cells aggravates aGvHD due to an increased systemic release of cytokines such as IL-6.

\section{GR ablation in recipient myeloid cells exacerbates aGvHD}

Pro-inflammatory cytokines such as IL-6 are expressed by a variety of recipient cell types. Since macrophages are one of their main sources, we determined the role of the GR in myeloid cells for disease severity and mortality of mice undergoing allogeneic HSCT. To address this issue, we took advantage of $\mathrm{GR}^{\text {lysm }}$ mice that lack the GR in several myeloid cell types [14] including macrophages that are for the most part resistant to irradiation during aGvHD induction [30]. GR flox control

A

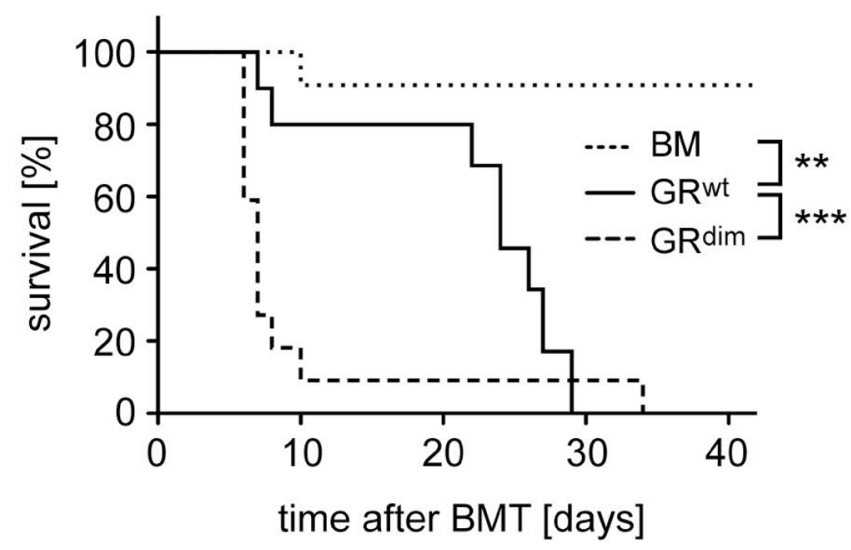

C

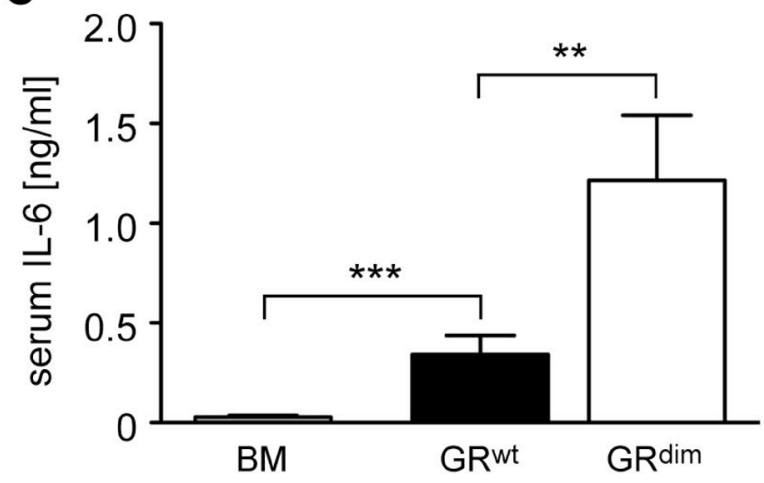

mice died between day 10 and 40 and showed the expected disease course characterized by progressively increasing clinical scores in the early phase of aGvHD and a gradually decreasing body temperature (Figure 3A-3C). In comparison, GR ${ }^{\text {lys }}$ mice developed more severe clinical symptoms on day 6 and 8 , which resulted in early lethality before day 10 (Figure 3A, 3B). Furthermore, the body temperature of $\mathrm{GR}^{\mathrm{lysM}}$ mice on day 8 was strongly reduced compared to $\mathrm{GR}^{\text {flox }}$ mice, which presumably contributes to their high mortality (Figure 3C). Collectively, GR deletion in recipient myeloid cells largely reproduces the aggravated aGvHD phenotype observed in GR ${ }^{\mathrm{dim}}$ mice.

\section{Disease severity in $\mathbf{G R}^{\mathrm{IysM}}$ mice does not coincide with target tissue damage}

To identify the pathogenic mechanisms explaining the difference in aGvHD severity between $\mathrm{GR}^{\text {flox }}$ and $\mathrm{GR}^{\text {lysM }}$ mice, we performed histological analyses of the intestine, one of the major aGvHD target organs. Histopathological
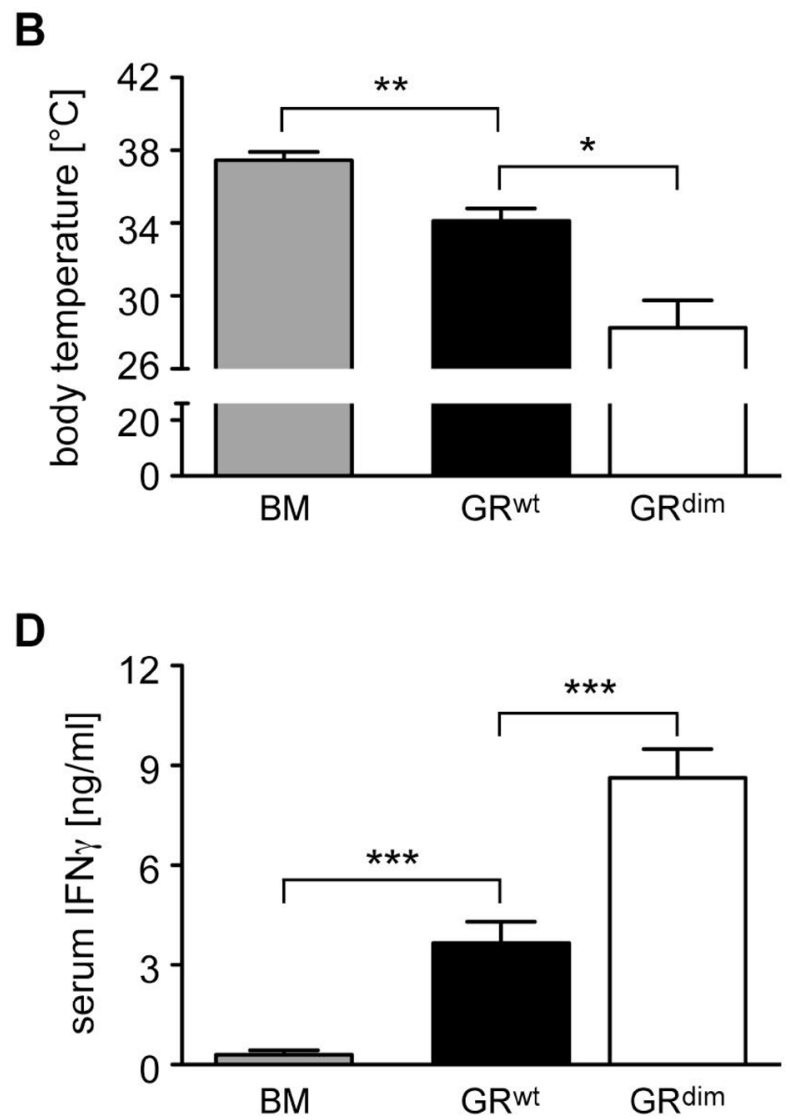

Figure 1: Mortality and clinical features of aGvHD in the $\mathbf{G R}^{\mathrm{dim}}$ model. $\mathrm{GR}^{\mathrm{wt}}$ and $\mathrm{GR} \mathrm{dim}^{\mathrm{dim}} \mathrm{BLB} / \mathrm{c}$ mice were transplanted with BM and purified T cells from C57BL/6 wildtype mice; transfer of BM cells only served as a control. (A) Survival of mice was monitored for 42 days. $N=11(\mathrm{BM}), N=10\left(\mathrm{GR}^{\mathrm{wt}}\right), N=22\left(\mathrm{GR}^{\mathrm{dim}}\right)$; data pooled from multiple experiments. (B) Body temperature of mice was analyzed on day 6. $N=6(\mathrm{BM}), N=7\left(\mathrm{GR}^{\mathrm{wt}}\right), N=9\left(\mathrm{GR}^{\mathrm{dim}}\right)$; data pooled from multiple experiments. $(\mathbf{C}, \mathbf{D})$ Mice were sacrificed on day 6 and serum levels of IL-6 (C) and IFN $\gamma(\mathrm{D})$ were analyzed by ELISA. $N=7(\mathrm{BM}), N=9\left(\mathrm{GR}^{\mathrm{wt}}\right), N=6\left(\mathrm{GR}^{\mathrm{dim}}\right)$ for IL-6; $N=7$ (BM), $N=13\left(\mathrm{GR}^{\mathrm{wt}}\right), N=15\left(\mathrm{GR}^{\mathrm{dim}}\right)$ for IFN $\gamma$; data pooled from multiple experiments. All values are depicted as the mean $\pm \mathrm{SEM}$. Survival curves were compared using the Gehan-Breslow-Wilcoxon test, statistical analyses of body temperature and cytokine levels were performed by Mann-Whitney $U$ test $\left({ }^{*} p<0.05 ;{ }^{* *} p<0.01 ;{ }^{* * *} p<0.001 ;\right.$ n.s.: non-significant). 
A

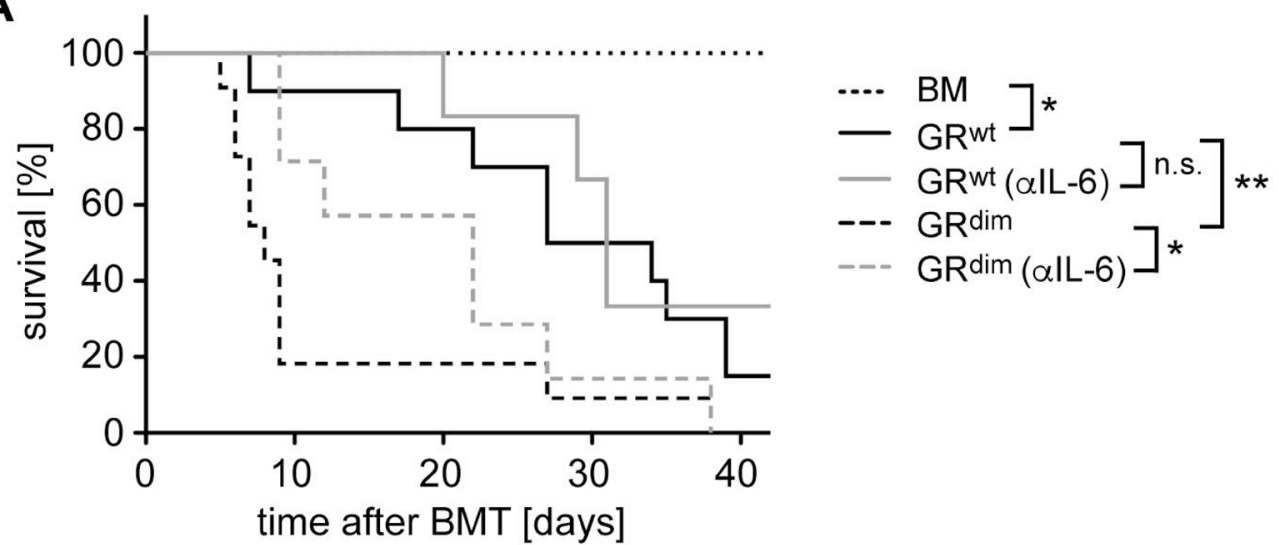

B

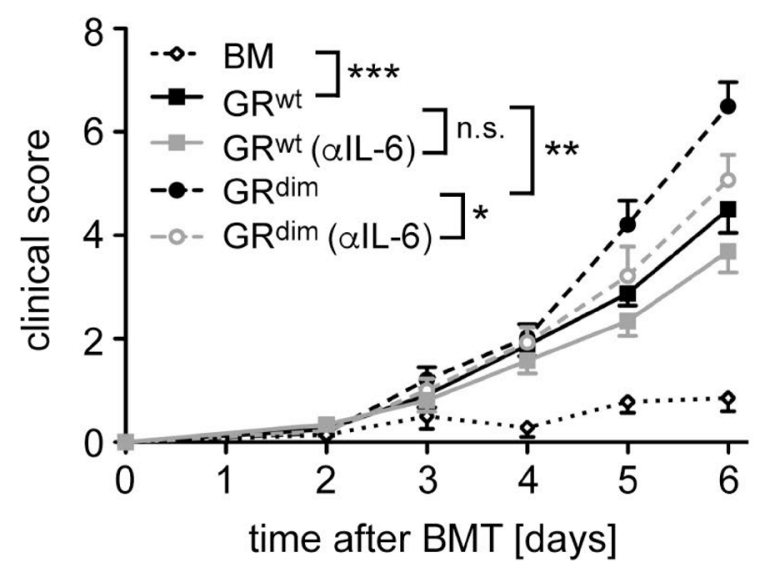

D

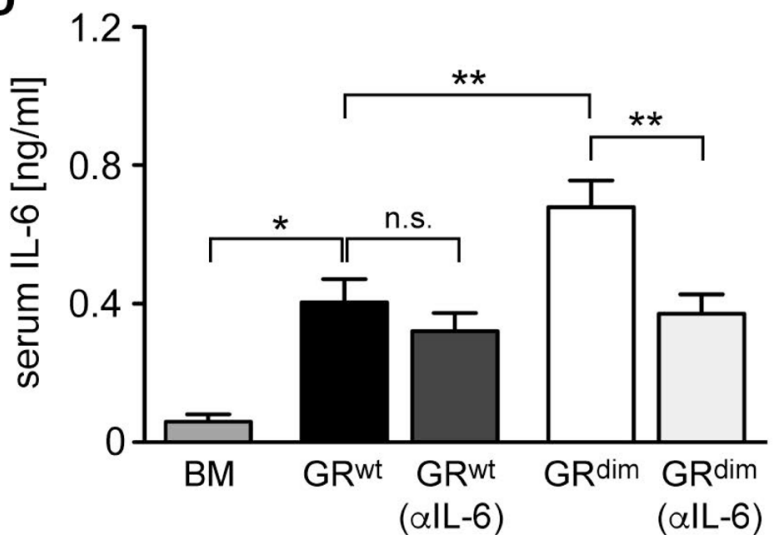

C

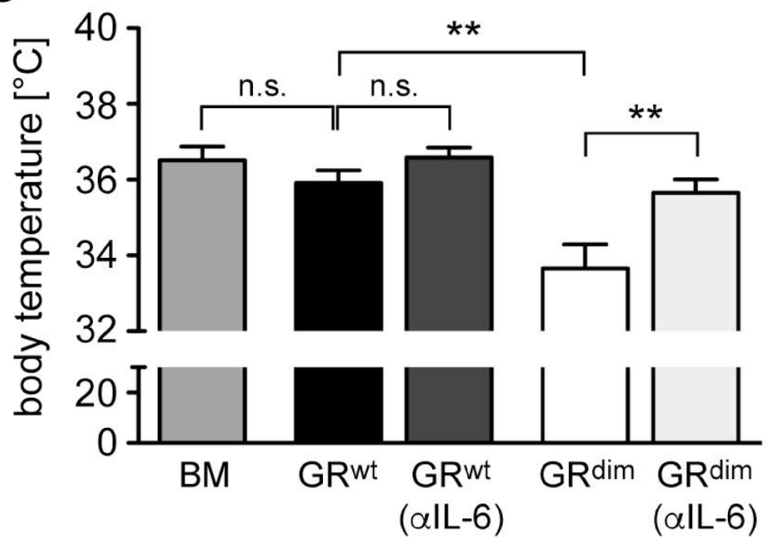

E

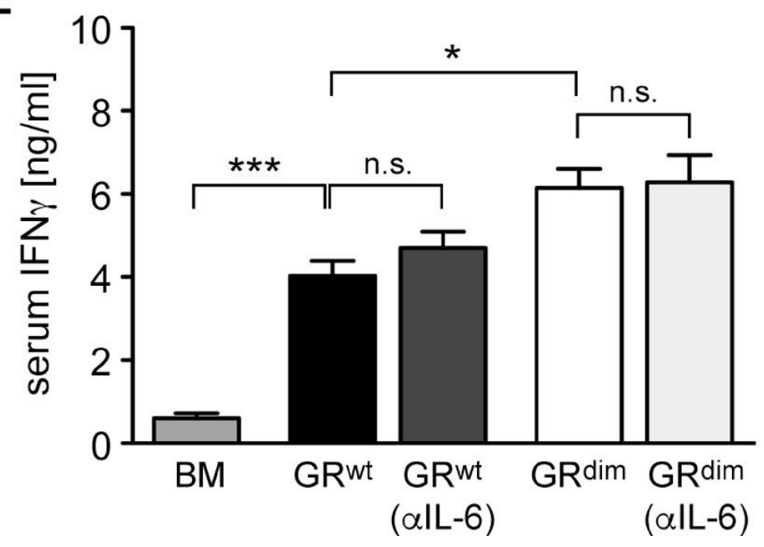

Figure 2: Impact of anti-IL-6 antibody treatment on mortality and clinical features of aGvHD in the GR ${ }^{\mathrm{dim}}$ model. GR $^{\mathrm{wt}}$ and $\mathrm{GR}^{\mathrm{dim}} \mathrm{BALB} / \mathrm{c}$ mice were transplanted with BM and purified T cells from C57BL/6 wildtype mice. Some mice received an anti-IL-6 ( $\alpha$ IL-6) antibody i.v. on day 2 (all panels) and day 6 (panel A); transfer of BM cells only served as a control. (A) Survival of mice was monitored for 42 days. $N=7$ (BM), $N=10 / 6\left(\mathrm{GR}^{\mathrm{wt}} \pm \alpha \mathrm{IL}-6\right), N=11 / 7$ (GR $\left.{ }^{\mathrm{dim}} \pm \alpha \mathrm{IL}-6\right)$; data pooled from multiple experiments. (B) Clinical scores of mice during the first 6 days after aGvHD induction (dead mice were considered with a score of 10$) . N=7(\mathrm{BM}), N=12 / 13\left(\mathrm{GR}{ }^{\mathrm{wt}}\right.$ $\pm \alpha \mathrm{IL}-6), N=19 / 14$ (GR $\left.{ }^{\mathrm{dim}} \pm \alpha \mathrm{IL}-6\right)$; data pooled from multiple experiments. (C) Body temperature of mice was analyzed on day $6 . N=7$ (BM), $N=15 / 13$ (GR $\left.{ }^{\mathrm{wt}} \pm \alpha \mathrm{IL}-6\right), N=22 / 13$ (GR $\left.{ }^{\mathrm{dim}} \pm \alpha \mathrm{IL}-6\right)$; data pooled from multiple experiments. (D, E) Mice were sacrificed on day 6 and serum levels of IL-6 (D) and IFN $\gamma$ (E) were analyzed by ELISA. $N=7$ (BM), $N=8 / 11\left(\mathrm{GR}^{\mathrm{wt}} \pm \alpha \mathrm{IL}-6\right), N=14 / 12\left(\mathrm{GR}{ }^{\mathrm{dim}} \pm \alpha \mathrm{IL}-6\right)$ for IL-6; $N=7(\mathrm{BM}), N=8 / 12\left(\mathrm{GR}^{\mathrm{wt}} \pm \alpha \mathrm{IL}-6\right), N=16 / 12\left(\mathrm{GR}^{\mathrm{dim}} \pm \alpha \mathrm{IL}-6\right)$ for IFN $\gamma$; data pooled from multiple experiments. All values are depicted as the mean \pm SEM. Survival curves were compared using the Gehan-Breslow-Wilcoxon test, statistical analyses of body temperature and cytokine levels were performed by One-way ANOVA followed by Newman-Keuls multiple comparison test $\left({ }^{*} p<0.05\right.$; ${ }^{* *} p<0.01 ;{ }^{* * *} p<0.001$; n.s.: non-significant). 

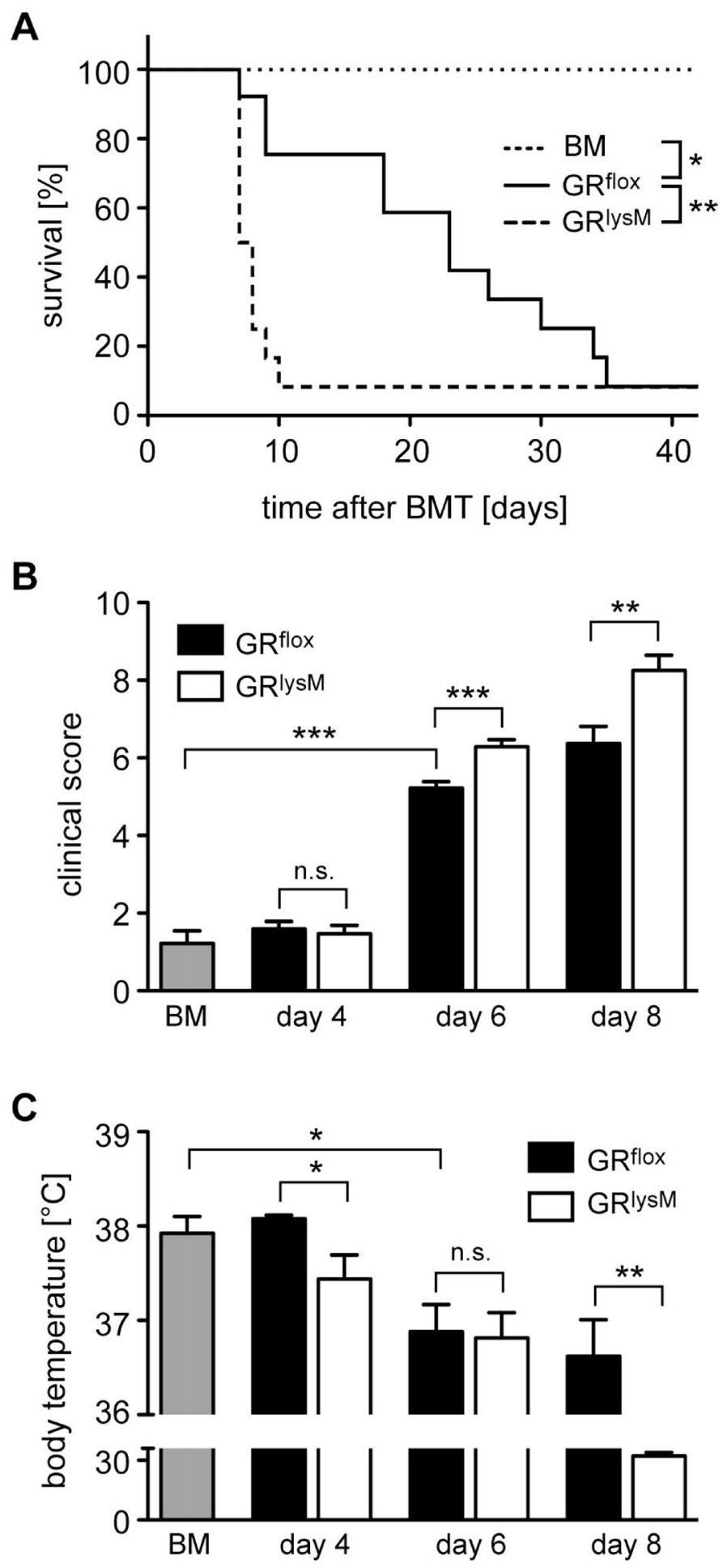

Figure 3: Mortality and clinical features of aGvHD in the GR $^{\mathrm{lysM}}$ model. $\mathrm{GR}^{\text {flox }}$ and $\mathrm{GR}^{\mathrm{lysM}} \mathrm{BALB} / \mathrm{c}$ mice were transplanted with $\mathrm{BM}$ and purified T cells from C57BL/6 wildtype mice; transfer of BM cells only served as a control. (A) Survival of mice was monitored for 42 days. $N=6(\mathrm{BM}), N=14\left(\mathrm{GR}^{\text {flox }}\right), N=13\left(\mathrm{GR}^{\text {lys }}\right)$; data pooled from multiple experiments. (B) Clinical scores were determined on day 4, 6 and 8 after aGvHD induction (dead mice were considered with a score of 10); analysis of BM controls was performed on day 6 . $N=9(\mathrm{BM}), N=31 / 31$ (GR ${ }^{\text {flox}} / \mathrm{GR}^{\text {lysm}}$; day 4$), N=39 / 40\left(\mathrm{GR}^{\text {flox}} / \mathrm{GR}^{\text {lysM }}\right.$; day 6$), N=19 / 20$ (GR ${ }^{\text {flox }} / \mathrm{GR}^{\text {lysm}}$; day 8$)$; data pooled from multiple experiments. (C) Body temperature was determined on day 4, 6 and 8 after aGvHD induction; analysis of BM controls was performed on day 6. $N=8(\mathrm{BM}), N=5 / 5\left(\mathrm{GR}^{\text {flox }} / \mathrm{GR}^{\text {lysm}}\right.$; day 4$), N=20 / 22\left(\mathrm{GR}^{\text {flox }} / \mathrm{GR}^{\text {lysm}}\right.$; day 6$), N=5 / 7$ (GR ${ }^{\text {flox}} / \mathrm{GR}^{\text {lysm}}$; day 8$)$; data pooled from multiple experiments. All values are depicted as the mean \pm SEM. Survival curves were compared using the Gehan-Breslow-Wilcoxon test, statistical analyses of clinical scores, body temperature and cytokine levels were performed by Mann-Whitney $U$ test $\left({ }^{*} p<0.05\right.$; ${ }^{* *} p<0.01 ;{ }^{* * *} p<0.001 ;$ n.s.: non-significant). 
assessment revealed significant tissue damage in the jejunum in the early phase of the disease, which was characterized by inflammatory infiltrates, apoptotic cells, villus blunting, edema, and a massive loss of goblet cells (Figure 4A). Tissue damage strongly increased from day 4 to day 8 , but despite the exacerbated disease in $\mathrm{GR}^{\text {lysM }}$ mice, histological scores and the number of goblet cells per villus were similar in both genotypes at all times (Figure 4B, 4C). In addition, we studied $\mathrm{CD}^{+} \mathrm{T}$ cells and $\mathrm{CD} 68^{+}$myeloid cells in sections of the jejunum by immunohistochemical staining (Figure 5A). Although the numbers of both types of immune cells were significantly elevated in aGvHD mice on day 6 , there were no differences in cellular infiltration between $\mathrm{GR}^{\text {flox }}$ and $\mathrm{GR}^{\text {lysM }}$ mice at any of the time points analyzed (Figure 5B, 5C). Remarkably, T cell numbers did not further increase on day 8 and macrophage numbers even decreased, probably reflecting the extensive distortion of the villi at this advanced stage of the disease (Figure 5B, 5C). Taken together, our findings indicate that the increased severity of aGvHD in GR ${ }^{\mathrm{lysM}}$ mice neither coincides with leukocyte infiltration nor subsequent tissue damage in the jejunum.

\section{GR deficiency in recipient myeloid cells has only a minor effect on local cytokine production in the jejunum}

A major function of the GR in macrophages is the suppression of pro-inflammatory mediators [31]. Hence we started to investigate whether GR ablation in myeloid cells had any impact on local cytokine production in aGvHD target organs. Initially, we isolated RNA from the jejunum and analyzed it by quantitative RT-PCR. IL-6, TNF $\alpha$ and IFN $\gamma$ mRNA levels strongly increased from day 4 to day 6 and declined again on day 8. IL- 6 and TNF $\alpha$ expression in $\mathrm{GR}^{\text {flox }}$ and $\mathrm{GR}^{\text {lysM }}$ mice was always similar while IFN $\gamma$ was slightly reduced on day 4 (Figure 6A). Of note, a similar pattern of gene regulation was observed
A

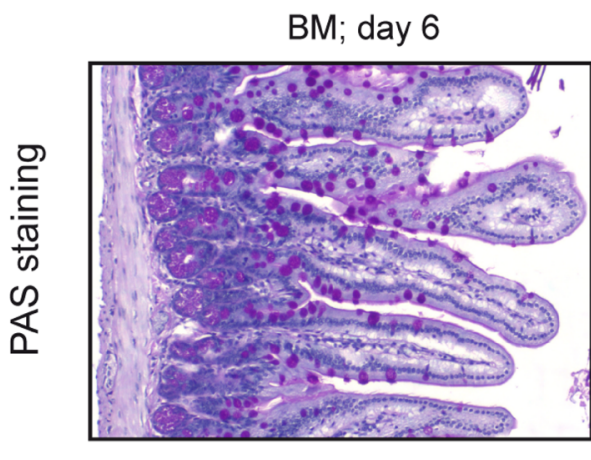

GRflox; day 6

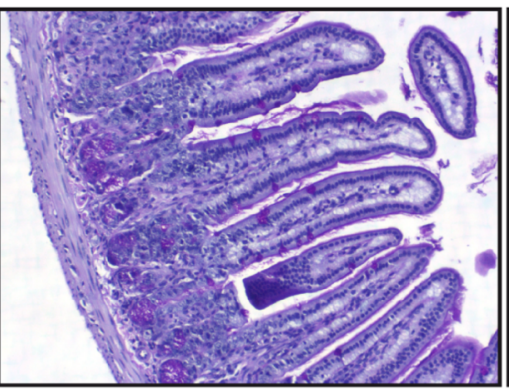

GRlysM; day 6

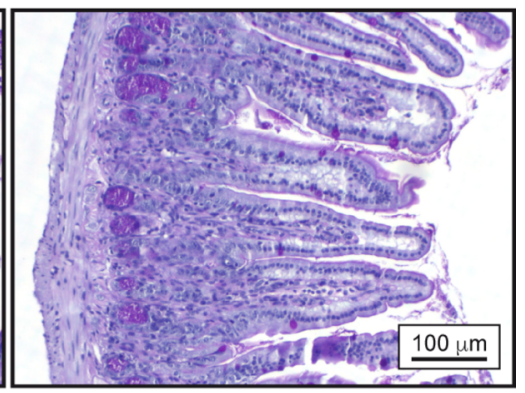

B

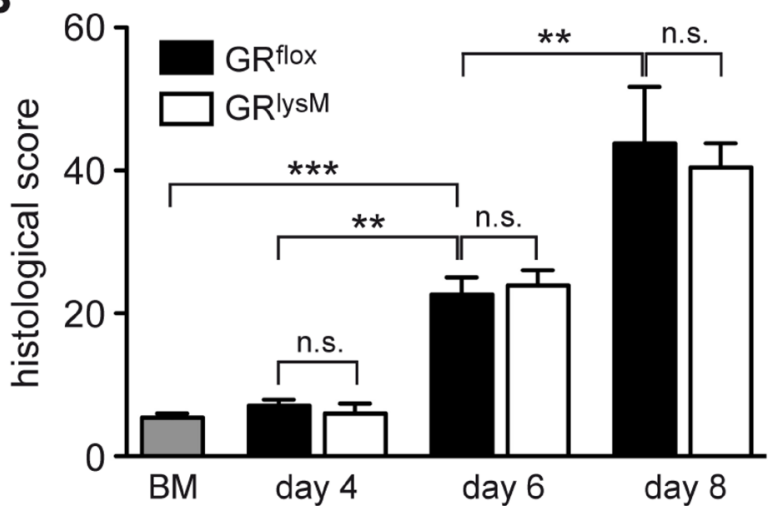

C

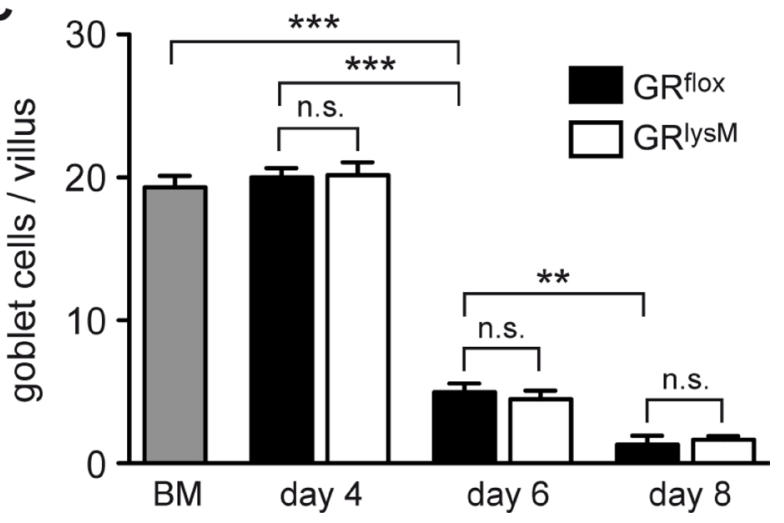

Figure 4: Histological assessment of the jejunum in the early phase of aGvHD in the GR ${ }^{\text {lysM }}$ model. GR $^{\text {flox }}$ and $\mathrm{GR}^{\mathrm{lysM}}$ $\mathrm{BALB} / \mathrm{c}$ mice were transplanted with $\mathrm{BM}$ and purified $\mathrm{T}$ cells from $\mathrm{C} 57 \mathrm{BL} / 6$ wildtype mice; transfer of BM cells only served as a control. Mice were sacrificed and analyzed on day 4, 6 and 8 after aGvHD induction; analysis of BM controls was performed on day 6 . (A) Representative microphotographs of sections of the jejunum collected on day 6 from BM control and aGvHD mice stained by PAS reaction. Size bar: $100 \mu \mathrm{m}$. (B) Histological scores obtained by assessment of H\&E stained jejunum sections from all experimental groups. $N=7(\mathrm{BM}), N=5 / 5$ (GR ${ }^{\text {flox}} / \mathrm{GR}^{\mathrm{lys}}$; day 4$), N=20 / 21$ (GR ${ }^{\text {flox }} / \mathrm{GR}^{\mathrm{lys} M}$; day 6$), N=6 / 7$ (GR ${ }^{\text {flox }} / \mathrm{GR}^{\mathrm{lys} M}$; day 8); data pooled from multiple experiments. (C) Goblet cell numbers per villus determined by PAS staining of jejunum sections from all experimental groups. $N=6$ (BM), $N=5 / 5\left(\mathrm{GR}^{\text {flox}} / \mathrm{GR}^{\mathrm{lys}}\right.$; day 4$), N=18 / 21$ (GR ${ }^{\text {flox}} / \mathrm{GR}^{\text {lysm}}$; day 6$), N=5 / 8\left(\mathrm{GR}^{\text {flox}} / \mathrm{GR}^{\text {lysm}}\right.$; day 8$)$; data pooled from multiple experiments. All values are depicted as mean $\pm \mathrm{SEM}$. Statistical analyses were performed by Mann-Whitney $U$ test $\left({ }^{* *} p<0.01 ;{ }^{* * *} p<0.001 ;\right.$ n.s.: nonsignificant). 
in the liver, another major aGvHD target organ (data not shown). To obtain insights into the local release of cytokines, we cultured jejunum biopsies for 24 hours and determined cytokine levels in the supernatant by ELISA. Secretion of IL-6, TNF $\alpha$ and IFN $\gamma$ in the jejunum did not match the regulatory pattern observed for the respective mRNA levels and showed considerable fluctuations during the early phase of the disease (Figure 6B). There were no differences concerning the release of IL- 6 and TNF $\alpha$ between both genotypes whereas the release of IFN $\gamma$ was slightly diminished on day 4 and elevated on day 6 (Figure 6B). Collectively, these results suggest that GR deficiency in recipient myeloid cells has no major impact on local cytokine production in aGvHD target organs.

\section{Systemic cytokine secretion in $\mathrm{GR}^{\mathrm{lysM}}$ mice is strongly increased}

Finally, we tested whether the fulminant disease in mutant mice coincided with unleashed systemic cytokine secretion. IL-6 and TNF $\alpha$ serum levels in diseased $\mathrm{GR}^{\text {flox }}$ mice were strongly increased in comparison to $\mathrm{BM}$ controls during the entire early phase of aGvHD (Figure 7). Systemic release of these two cytokine was similar in both genotypes on day 4 while it was modestly higher in GR ${ }^{\text {lysM }}$ mice on day 6 (Figure 7). Around the time when the majority of mutant mice succumb to the disease, secretion of IL-6 and TNF $\alpha$ in mutant mice was massively increased. IL-6 serum levels in GR ${ }^{\text {lys }}$ mice on day 8 were

A

$\mathrm{BM}$; day 6

GRflox; day 6

GRlysM; day 6

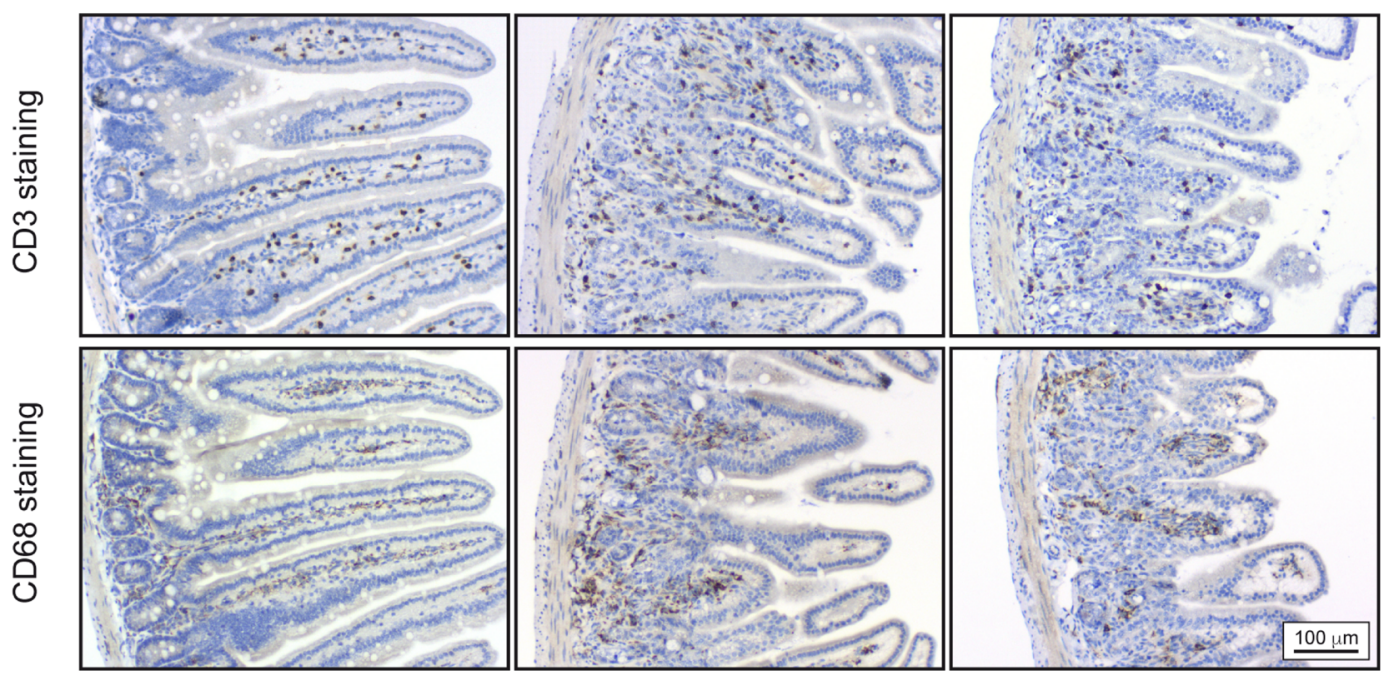

B

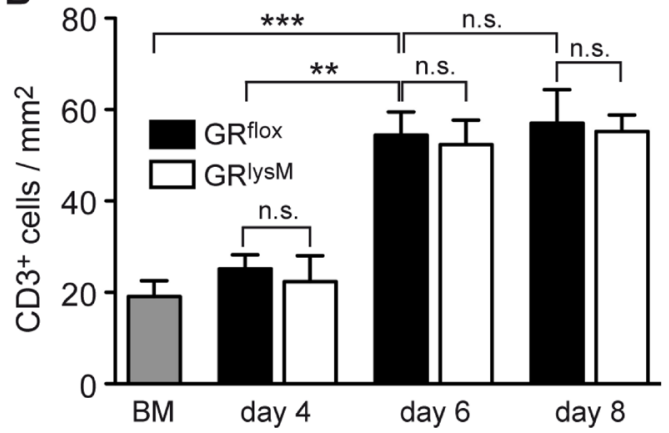

C

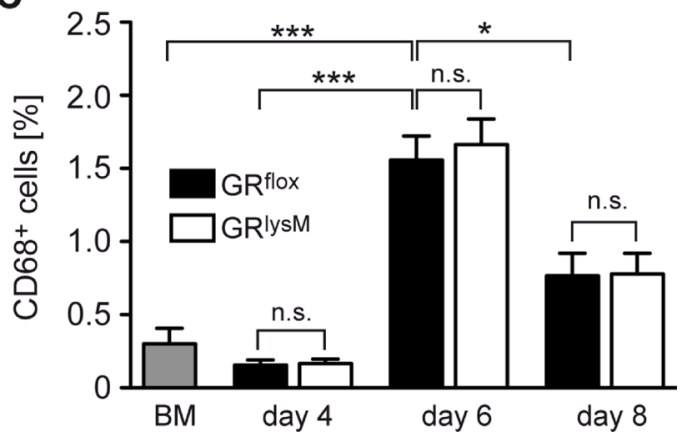

Figure 5: Immunohistochemical assessment of the jejunum in the early phase of aGvHD in the GR $^{\text {lysM }}$ model. GR ${ }^{\text {flox }}$ and $\mathrm{GR}^{\mathrm{IysM}} \mathrm{BALB} / \mathrm{c}$ mice were transplanted with $\mathrm{BM}$ and purified $\mathrm{T}$ cells from $\mathrm{C} 57 \mathrm{BL} / 6$ wildtype mice; transfer of $\mathrm{BM}$ cells only served as a control. Mice were sacrificed and analyzed on day 4, 6 and 8 after aGvHD induction; analysis of BM controls was performed on day 6. (A) Representative microphotographs of sections of the jejunum collected on day 6 from BM control and aGvHD mice and stained with antibodies recognizing CD3 (upper panel) or CD68 (lower panel). Size bar: $100 \mu \mathrm{m}$. (B) Numbers of CD3 ${ }^{+}$cells per $\mathrm{mm}^{2}$ were determined by computer-aided counting of stained cells in jejunum sections from all experimental groups using ImageJ software. $N=7$ (BM), $N=5 / 5\left(\mathrm{GR}^{\mathrm{flox}} / \mathrm{GR}^{\mathrm{IysM}}\right.$; day 4), $N=20 / 21\left(\mathrm{GR}^{\mathrm{flox}} / \mathrm{GR}^{\mathrm{lys} \mathrm{M}} ;\right.$ day 6$), N=6 / 7\left(\mathrm{GR}^{\mathrm{flox}} / \mathrm{GR}^{\mathrm{lys}}\right.$; day 8); data pooled from multiple experiments. (C) $\mathrm{CD} 68^{+}$cells were enumerated in jejunum sections from all experimental groups by measuring the percentage of stained area using ImageJ

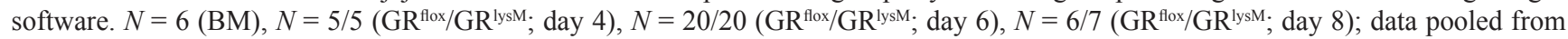
multiple experiments. All values are depicted as mean \pm SEM. Statistical analyses were performed by Mann-Whitney $U$ test ( ${ }^{*} p<0.05$; ${ }^{* *} p<0.01 ;{ }^{* * *} p<0.001$; n.s.: non-significant). 
eightfold higher than in GR ${ }^{\text {flox }}$ mice and TNF $\alpha$ levels were sixfold elevated (Figure 7). In contrast, secretion of IFN $\gamma$ was highest on day 4 and then declined without being significantly different between both genotypes at any time point analyzed (Figure 7). We conclude that deletion of the GR in recipient myeloid cells results in a cytokine storm characterized by fulminant systemic IL- 6 and TNF $\alpha$ release, which progressively exacerbates until most GR ${ }^{\text {lysm }}$ mice succumb to the disease.

A

jejunum expression
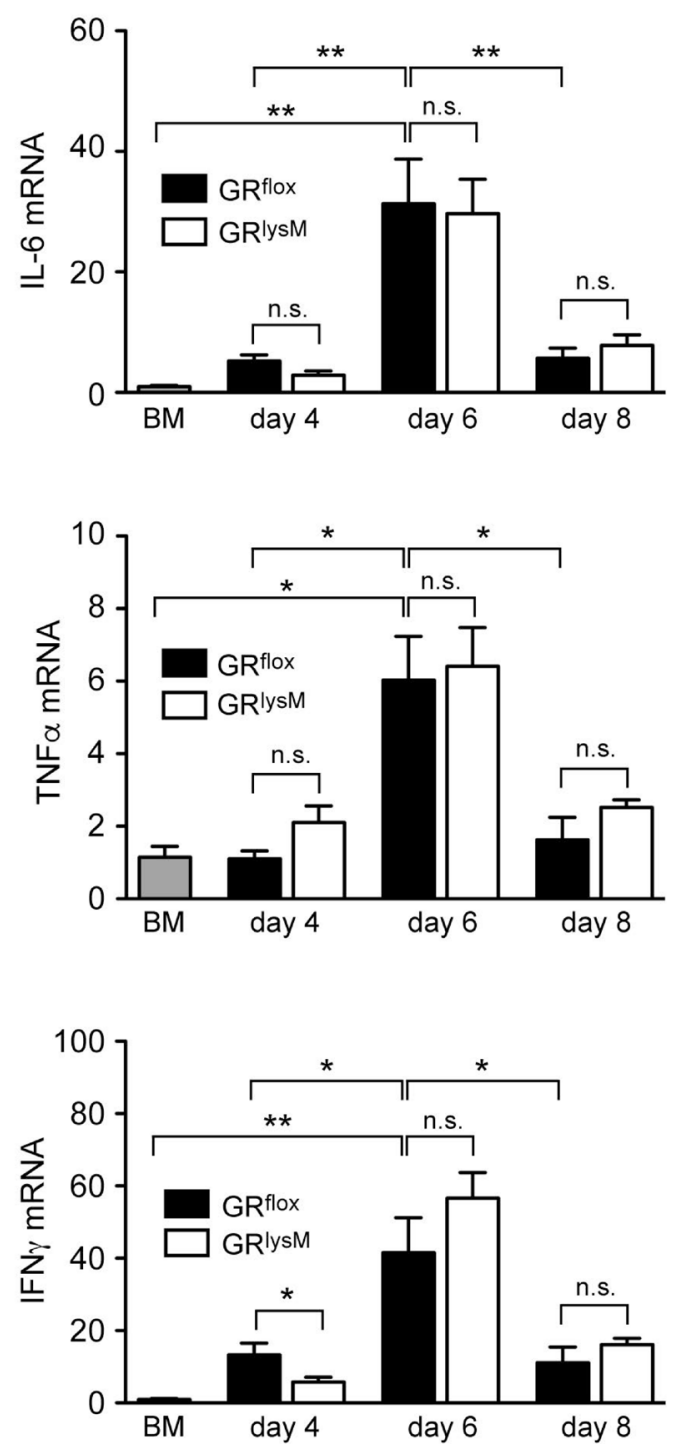

\section{DISCUSSION}

Different types of hematopoietic and nonhematopoietic cells contribute to the pathogenesis of aGvHD, and all of them express the GR. Our previous study revealed that $\mathrm{T}$ cells contained in the transplant are crucial targets of GC since deleting the GR in these cells resulted in an exacerbated disease course and early lethality [24]. It turned out that GC serve to repress pro-inflammatory

B jejunum secretion
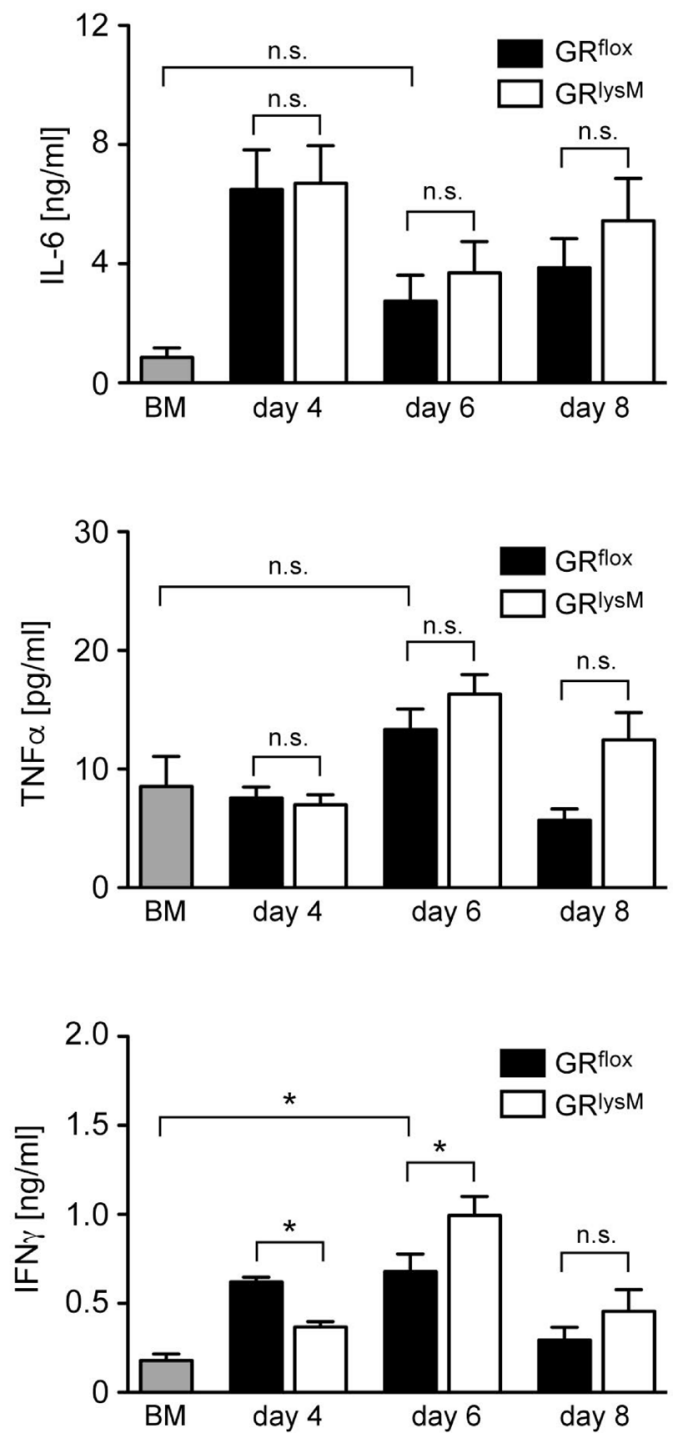

Figure 6: Cytokine expression and secretion in the jejunum in the early phase of aGvHD in the GR R $^{\text {lysM }}$ model. GR ${ }^{\text {flox }}$ and $\mathrm{GR}^{\mathrm{lys} M} \mathrm{BALB} / \mathrm{c}$ mice were transplanted with BM and purified T cells from C57BL/6 wildtype mice; transfer of BM cells only served as a control. Mice were sacrificed and analyzed on day 4,6 and 8 after aGvHD induction; analysis of BM controls was performed on day 6. (A) Relative mRNA levels of IL-6, TNF $\alpha$ and IFN $\gamma$ in jejunum biopsies were determined by quantitative RT-PCR using HPRT for normalization. Gene expression in BM control mice was arbitrarily set to $1 . N=4(\mathrm{BM}), N=5 / 5\left(\mathrm{GR}^{\text {flox}} / \mathrm{GR}^{\text {lysm}} ;\right.$ day 4$), N=12 / 15\left(\mathrm{GR}{ }^{\text {flox} /}\right.$ $\mathrm{GR}^{\text {lysM}}$; day 6$), N=5 / 7$ ( $\mathrm{GR}^{\text {flox }} / \mathrm{GR}^{\text {lysM }}$; day 8$)$; data pooled from multiple experiments. (B) Jejunum biopsies were cultured for 24 hours in RPMI+ medium and IL-6, TNF $\alpha$ and IFN $\gamma$ levels in the supernatant were determined by ELISA. $N=4(\mathrm{BM}), N=5 / 5\left(\mathrm{GR}^{\text {flox }} / \mathrm{GR}^{\text {lysm}}\right.$; day 4), $N=14 / 15$ ( $\mathrm{GR}^{\text {flox }} / \mathrm{GR}^{\text {lysm}}$; day 6$), N=6 / 8\left(\mathrm{GR}^{\text {flox }} / \mathrm{GR}^{\text {lysM }}\right.$; day 8$)$; data pooled from multiple experiments. All values are depicted as mean \pm SEM. Statistical analyses were performed by Mann-Whitney $U$ test $\left({ }^{*} p<0.05\right.$; n.s.: ${ }^{* *} p<0.01$; n.s.: non-significant $)$. 


\section{serum level}
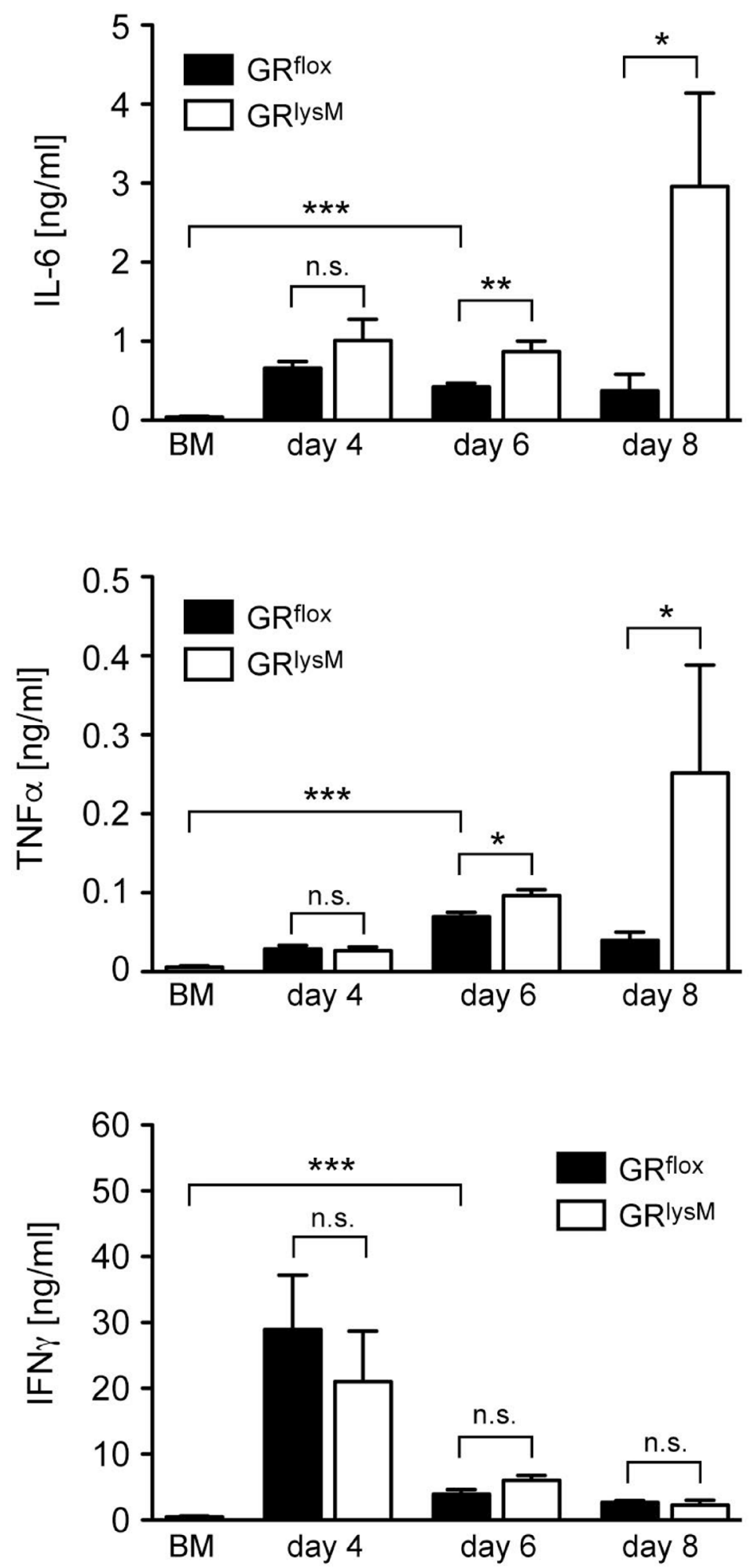

Figure 7: Cytokine serum levels in the early phase of aGvHD in the GR $^{\text {lysM }}$ model. GR ${ }^{\text {flox }}$ and GR ${ }^{\text {lysm }}$ BALB/c mice were transplanted with BM and purified T cells from C57BL/6 wildtype mice; transfer of BM cells only served as a control. Mice were sacrificed and analyzed on day 4, 6 and 8 after aGvHD induction; analysis of BM controls was performed on day 6. Serum levels of IL-6, TNF $\alpha$ and IFN $\gamma$ were determined by ELISA and are depicted as mean values $\pm \mathrm{SEM} . N=12(\mathrm{BM}), N=5 / 5\left(\mathrm{GR}^{\mathrm{flox}} / \mathrm{GR}^{\mathrm{lys}} ; \mathrm{day}^{4}\right), N=27 / 28$ $\left(\mathrm{GR}^{\text {flox }} / \mathrm{GR}^{\mathrm{lys} \text {; }}\right.$ d day 6$), N=6 / 7$ (GR ${ }^{\text {flox }} / \mathrm{GR}^{\text {lysm}}$; day 8$)$; data pooled from multiple experiments. Statistical analyses were performed by MannWhitney $U$ test $\left({ }^{*} p<0.05 ;{ }^{* *} p<0.01 ;{ }^{* * *} p<0.001 ;\right.$ n.s.: non-significant). 
cytokines and cytotoxic molecules in transplanted T cells and thereby reduce tissue damage. Using a single MHC class I disparate aGvHD mouse model we could further demonstrate that cytotoxic $\mathrm{T}$ cells were the predominant cell type that needs to be controlled by GC in order to prevent fulminant disease [24]. However, it remained elusive up to now whether the role of GC was restricted to transplanted $\mathrm{T}$ cells or whether their impact on cells of the recipient was also important. Our current data provide evidence that this is indeed the case. While GR expression in recipient myeloid cells had no influence on the extent of tissue damage, suppression of macrophages by endogenous GC was essential to counteract systemic cytokine release in the early phase of the disease.

GR knock-out mice are not viable due to a defect in lung maturation [25]. Hence we took advantage of $\mathrm{GR}^{\mathrm{dim}}$ mice to investigate the role of GC in recipient cells. These mice harbor a point mutation which disrupts the GR dimerization interface [15]. Consequently, gene regulation by GC is largely abolished, in particular as far as homodimeric DNA-binding of the GR is concerned [26]. Previous studies in several models of sepsis had revealed that $\mathrm{GR}^{\mathrm{dim}}$ mice are highly prone to systemic inflammation, resulting in an enhanced mortality due to the inability to downregulate proinflammatory cytokines $[17,32]$. Just like sepsis, aGvHD is also characterized by systemic inflammation. Thus aGvHD induction is accompanied by increased levels of pro-inflammatory cytokines, an effect which was strongly aggravated in GR ${ }^{\mathrm{dim}}$ mice. While LPS-induced sepsis in these mutants could be counteracted by application of an IL-1R antagonist [17], the results presented here revealed that anti-IL-6 antibody treatment reduced disease severity and mortality in a mouse model of aGvHD. Collectively, these findings indicate that the GR is required to limit systemic inflammation caused by cytokine hypersecretion.

Having found that suppression of IL- 6 release by cells of recipient mice was crucial for the control of aGvHD, we aimed to identify the cell type being responsible for this effect. Cytokines such as IL-6 are produced by a variety of hematopoietic and non-hematopoietic cells. Since macrophages are an important source of these mediators, we studied aGvHD induction in $\mathrm{GR}^{\text {lysM }}$ mice. Notably, the mutants express a cre recombinase that causes GR deletion in various myeloid cell types such as neutrophils and macrophages [14]. However, amongst those ones only the latter resist irradiation during aGvHD induction [30]. Analysis of disease symptoms and mortality revealed that aGvHD was strongly aggravated in GR ${ }^{\text {lysM }}$ mice compared to $\mathrm{GR}^{\text {flox }}$ controls, although tissue damage and numbers of $\mathrm{T}$ cells and myeloid cells in the gastrointestinal tract, one of the major aGvHD target organs, were surprisingly similar in both genotypes. This finding led us to conclude that repression of myeloid cells by endogenous GC is crucial for aGvHD outcome albeit fulminant disease in the absence of the GR does not coincide with tissue damage in the jejunum in the initial phase of the disease.
IL-6, TNF $\alpha$ and IFN $\gamma$ are key pathogenic molecules in inflammatory diseases such as aGvHD. Accordingly, blockade of IL-6 ameliorated aGvHD in mice and tocilizumab, a monoclonal antibody that binds to the IL-6 receptor, shows activity in patients that failed to improve after GC administration [28, 29, 33]. Similarly, neutralization of TNF $\alpha$ prolonged survival in a mouse model of aGVHD and administration of the anti-TNF $\alpha$ monoclonal antibody infliximab is associated with an efficient clinical response $[34,35]$. In contrast, the exact role of IFN $\gamma$ in aGvHD remains controversial [36]. Experimental data suggest that IFN $\gamma$ is not required for the development of aGvHD and may even exert an inhibitory effect [37]. It is against this background that we analyzed regulation of these cytokines in GR ${ }^{\mathrm{lys}}$ mice. GR ablation in myeloid cells had basically no effect on gene expression in the jejunum. IL-6, TNF $\alpha$ and IFN $\gamma$ mRNA levels increased from day 4 to day 6 regardless of the genotype and declined again on day 8 . This expression pattern presumably reflects the inflammatory response that progressively develops in the first few days after HSCT and is followed by a transient resolution [38]. Local cytokine release followed a different pattern that was characterized by considerable fluctuations but again, we hardly observed any differences between mice of both genotypes irrespective of the stage of the disease. In stark contrast to the local regulation of cytokine production, systemic IL- 6 and TNF $\alpha$ release was strongly enhanced in mutant mice. While this difference was still moderate on day 6, fulminant cytokine secretion in GR ${ }^{\text {lysM }}$ mice was observed around the peak of the disease on day 8 when the majority of mutant mice succumb to the disease $[24,27]$. In contrast, IFN $\gamma$ serum levels in mice of both genotypes were highest on day 4 and declined thereafter, which coincides with the onset of T cell infiltration into the intestinal tract [38]. Taken together, we propose that the fulminant disease in $\mathrm{GR}^{\mathrm{lysM}}$ mice is a consequence of the overshooting systemic release of IL- 6 and TNF $\alpha$ whereas local production of these cytokines in aGvHD target organs is less critical. This situation can presumably be explained by the different origin of myeloid cells in distinct locations in the body. Myeloid cells in non-inflamed organs of GR ${ }^{\text {lysM }}$ mice are refractory to the repressive effects of GC due to the ablation of the GR. In contrast, many of the myeloid cells present in aGvHD target organs express the GR since they are derived from wildtype monocytes that are contained in the graft and preferentially migrate to the sites of inflammation. Thus one can expect differences in cytokine regulation to be more pronounced on the systemic than on the local level. Collectively, our findings suggests that the exacerbated cytokine storm is the major cause of mortality in GR ${ }^{\text {lysM }}$ mice, which is in accordance with a study in a model of LPS-induced sepsis where increased lethality of mutant mice has also been linked to cytokine hypersecretion [17].

GC are employed to treat inflammatory conditions in the context of allergy, autoimmunity, transplantation, 
and infectious diseases, but therapy is complicated by side effects that arise due to unspecific activities of these drugs. Accordingly, first-line therapy of aGvHD can cause muscle atrophy, osteoporosis or diabetes [9, 10, 39]. To overcome these limitations, targeted administration of GC would be desirable. Our findings reported here suggest that selective GC delivery to macrophages might allow ameliorating some aGvHD symptoms while causing less side effects. A variety of carrier systems have been developed for GC application during recent years and tested in different models of inflammation and cancer [40]. For example, treatment with Dex palmitate, a liposteroid preferentially taken up by macrophages, attenuated clinical symptoms and improved survival in an aGvHD mouse model, thereby confirming the feasibility of drug targeting in this disorder [41]. Based on these findings and the ones presented here, it is intriguing to speculate that therapies involving the specific delivery of GC to macrophages might result in a better benefit-to-risk profile compared to currently available regimens.

\section{MATERIALS AND METHODS}

\section{Ethics statement}

All animal experiments were conducted according to national and international guidelines and approved by the responsible authority of Lower Saxony (Niedersächsisches Landesamt für Verbraucherschutz und Lebensmittelsicherheit).

\section{Animal experimentation}

$\mathrm{GR}^{\mathrm{wt}}$ and $\mathrm{GR}^{\mathrm{dim}}\left(\mathrm{Nr} 3 \mathrm{c}^{\mathrm{tm} 3 \mathrm{GSc}}\right)$ mice as well as $\mathrm{GR}^{\text {flox }}$ and $\mathrm{GR}^{\text {lysM }}\left(\mathrm{Nr} 3 \mathrm{c}^{\text {tm2GSc}}{ }^{\mathrm{Lyz}} 2^{\mathrm{tm} 1(\mathrm{Cr}) / \mathrm{fo}}\right)$ mice were on a BALB/c background and described earlier $[14,15]$. C57BL/6 wildtype mice were purchased from Charles River (Sulzfeld, Germany) or Janvier Labs (St. Berthevin, France). All mice were kept in individually ventilated cages under specific-pathogen-free conditions at our animal facility at the University Medical Center Goettingen, supplied with food and water ad libitum, and used at an age of 8-12 weeks. To neutralize IL-6, mice were injected intravenously (i.v.) on day 2 , and if applicable, additionally on day 6 with $100 \mu \mathrm{g}$ of an anti-IL6 antibody (clone MP520F3, $1 \mathrm{mg} / \mathrm{ml}$; eBioscience, Frankfurt, Germany).

\section{aGvHD mouse model}

BM was isolated from tibiae, femura and humeri of C57BL/6 wildtype mice and passed through a $100 \mu \mathrm{m}$ cell strainer. T cells were depleted from the BM by using anti-CD90.2 microbeads (Miltenyi Biotech, Bergisch Gladbach, Germany) or the EasySep ${ }^{\text {TM }}$ Positive Selection Mouse CD90.2 Kit II (StemCell Technologies, Grenoble, France). Contaminating T cells in BM preparations were
$<1 \%$ as assessed by flow cytometry. Mature T cells were prepared from spleen and lymph nodes by passing the freshly dissected organs through a $40 \mu \mathrm{m}$ cell strainer and subsequent purification with the help of the EasySep ${ }^{\mathrm{TM}}$ Negative Selection Mouse T Cell Isolation Kit as per the manufacturer's instructions (StemCell Technologies). Flow cytometric analysis revealed that the purity of $\mathrm{T}$ cell preparations was routinely $>95 \%$.

$\mathrm{BALB} / \mathrm{c}$ mice of the different genotypes were subjected to total body irradiation with a dose of 8.5 Gy using an X-Ray source operated at $200 \mathrm{kV}, 15 \mathrm{~mA}$ and $0.5-\mathrm{mm} \mathrm{Cu}$ filtration. On the next day, $1 \times 10^{7} \mathrm{BM}$ cells and $2 \times 10^{6} \mathrm{~T}$ cells were injected via the tail vein to induce aGvHD. Injection of $1 \times 10^{7} \mathrm{BM}$ cells only served as a control. Antibiosis was achieved by supplementing the drinking water with $25 \mu \mathrm{g} / \mathrm{ml}$ neomycin for up to three weeks starting one day prior to irradiation. Disease severity was monitored using a scoring system based on five parameters: posture, activity, fur ruffling, diarrhea and weight loss [24]. Each parameter was assigned a score between 0 (no symptoms) and 2 (severe symptoms), resulting in a total score of 0 to 10 . Mice which died or had to be sacrificed for ethical reasons were assigned a score of 10 for the rest of the experiment. The body temperature of mice was measured using a BIO-TK9882 thermometer which was equipped with a BIO-BRET-3 rectal probe (Bioseb, Vitrolles, France).

\section{ELISA}

Blood samples were obtained by cardiac puncture, left for coagulation at room temperature for 30 minutes, and centrifuged to separate the serum. The jejunum was flushed with ice-cold PBS and four pieces of $5 \mathrm{~mm}$ length from different sites of the jejunum were incubated for 24 hours in RPMI medium supplemented with $10 \%$ FCS and 1\% Penicillin/Streptomycin (designated RPMI+) at $37^{\circ} \mathrm{C}$ in a $5 \% \mathrm{CO}_{2}$ atmosphere. The supernatant was removed for analysis and the jejunum pieces were weighted as a means to correct for differences in their size. Levels of IL-6, TNF $\alpha$ and IFN $\gamma$ were determined by ELISA using commercially available kits according to the manufacturer's instructions (BioLegend, Uithoorn, The Netherlands).

\section{Histology}

Tissue biopsies were fixed for 48 hours in 4\% PFA (Carl Roth, Karlsruhe, Germany) at room temperature and subsequently dehydrated and embedded in paraffin. 2 $\mu \mathrm{m}$ sections were prepared and stained with hematoxylin and eosin (H\&E) or by Periodic acid-Schiff reaction (PAS) according to standard protocols. Photomicrographs were acquired using a Leica Axio Scope A1 microscope (Wetzlar, Germany). Histopathological scores were determined in a blinded manner by evaluating four criteria in ten fields per section [42]: (A) villous blunting/ 
flattening ( $0=$ none, $1=$ yes; $20 \times$ magnification $)$, (B) number of apoptotic cells (40× magnification), (C) grade of inflammation $(0=$ none, $1=$ mild, $2=$ moderate without abscess, 3 = presence of abscess, erosions or ulcer; $20 \times$ magnification), (D) edema $(0=$ none, $1=$ yes; $20 \times$ magnification). The total histopathological score assigned to each section was calculated as the sum of individual scores obtained for each criterion in all fields. The average number of goblet cells per villus was determined by counting PAS-positive cells in a total of ten villi at $40 \times$ magnification.

\section{Immunohistochemistry}

For immunohistochemical stainings, $2 \mu \mathrm{m}$ tissue sections were incubated in EnVision Flex Target Retrival Solution, Low pH (Dako Agilent Technologies, Santa Clara, CA). This step was followed by incubation with primary antibodies recognizing CD3 (1:2000; Santa Cruz Biotechnology) or CD68 (1:200; Abcam, Cambridge, UK) for 30 minutes at room temperature. Polymeric secondary antibodies coupled to HRP (mmPRESS HRP Polymer Detection Kit; Vector Laboratories, Burlingame, CA) and DAB (Dako Agilent Technologies) were employed to visualize the sites of immunoreactivity. Counterstaining was done with hematoxylin. Photomicrographs were acquired using a Leica Axio Scope A1 microscope and quantified after taking ten pictures per section at $20 \mathrm{x}$ magnification. To this end, pictures were processed using ImageJ (https://imagej.nih.gov/ij/) either by counting individual cells (CD3) or by measuring the stained tissue areas (CD68).

\section{RNA isolation and quantitative RT-PCR}

Total RNA was isolated with the RNeasy Mini Kit (Qiagen, Hilden, Germany) and reverse transcribed into cDNA using the iScript Kit (Bio-Rad, Munich, Germany). Quantitative RT-PCR was performed on an ABI 7500 instrument (Applied Biosystems, Darmstadt, Germany) by employing the SYBR mastermix from the same company. Results were normalized to mRNA expression of HPRT and evaluated using the $\Delta \Delta \mathrm{Ct}$ method. All primers were synthesized by Metabion (Planegg, Germany); the sequences are available upon request.

\section{Statistical analysis}

All data were analyzed using Prism ${ }^{\circledR}$ (GraphPad Software, San Diego, CA). The Mann-Whitney $U$ test was used for comparisons of two individual groups, a One-way ANOVA followed by Newman-Keuls test was used to analyze multiple groups, and the Gehan-BreslowWilcoxon test was employed for the analysis of KaplanMeier survival curves. Levels of significance: ${ }^{*} p<0.05$, ${ }^{* *} p<0.01,{ }^{* * *} p<0.001$, n.s.: non-significant.

\section{ACKNOWLEDGMENTS}

We would like to thank Amina Bassibas and Jennifer Appelhans for expert technical assistance.

\section{CONFLICTS OF INTEREST}

The authors declare no conflicts of interest.

\section{FUNDING}

This work was supported by the Deutsche Forschungsgemeinschaft (RE1631/15-1 to H.M.R, Tu220/131 and INST 40/492-1 CRC 1149 to J.P.T.), intramural funds of the University Medical Center Goettingen and the Open Access Publication Funds of the Georg-August-University Goettingen.

\section{REFERENCES}

1. Ferrara JL, Levine JE, Reddy P, Holler E. Graft-versus-host disease. Lancet. 2009; 373:1550-1561.

2. Shlomchik WD. Graft-versus-host disease. Nat Rev Immunol. 2007; 7:340-352.

3. Shlomchik WD, Couzens MS, Tang CB, McNiff J, Robert ME, Liu J, Shlomchik MJ, Emerson SG. Prevention of graft versus host disease by inactivation of host antigenpresenting cells. Science. 1999; 285:412-415.

4. Hill GR, Crawford JM, Cooke KR, Brinson YS, Pan L, Ferrara JL. Total body irradiation and acute graft-versushost disease: the role of gastrointestinal damage and inflammatory cytokines. Blood. 1997; 90:3204-3213.

5. Petersdorf EW, Longton GM, Anasetti C, Mickelson EM, McKinney SK, Smith AG, Martin PJ, Hansen JA. Association of HLA-C disparity with graft failure after marrow transplantation from unrelated donors. Blood. 1997; 89:1818-1823.

6. Martin PJ, Weisdorf D, Przepiorka D, Hirschfeld S, Farrell A, Rizzo JD, Foley R, Socie G, Carter S, Couriel D, Schultz $\mathrm{KR}$, Flowers ME, Filipovich AH, et al, and Design of Clinical Trials Working Group. National Institutes of Health Consensus Development Project on Criteria for Clinical Trials in Chronic Graft-versus-Host Disease: VI. Design of Clinical Trials Working Group report. Biol Blood Marrow Transplant. 2006; 12:491-505.

7. Harris AC, Ferrara JL, Levine JE. Advances in predicting acute GVHD. Br J Haematol. 2013; 160:288-302.

8. Martin PJ, Rizzo JD, Wingard JR, Ballen K, Curtin PT, Cutler C, Litzow MR, Nieto Y, Savani BN, Schriber JR, Shaughnessy PJ, Wall DA, Carpenter PA. First- and secondline systemic treatment of acute graft-versus-host disease: recommendations of the American Society of Blood and Marrow Transplantation. Biol Blood Marrow Transplant. $2012 ; 18: 1150-1163$. 
9. Rauch A, Seitz S, Baschant U, Schilling AF, Illing A, Stride B, Kirilov M, Mandic V, Takacz A, SchmidtUllrich R, Ostermay S, Schinke T, Spanbroek R, et al. Glucocorticoids suppress bone formation by attenuating osteoblast differentiation via the monomeric glucocorticoid receptor. Cell Metab. 2010; 11:517-531.

10. Watson ML, Baehr LM, Reichardt HM, Tuckermann JP, Bodine SC, Furlow JD. A cell-autonomous role for the glucocorticoid receptor in skeletal muscle atrophy induced by systemic glucocorticoid exposure. Am J Physiol Endocrinol Metab. 2012; 302:E1210-1220.

11. Mosser DM, Edwards JP. Exploring the full spectrum of macrophage activation. Nat Rev Immunol. 2008; 8:958-969.

12. Martinez FO, Sica A, Mantovani A, Locati M. Macrophage activation and polarization. Front Biosci. 2008; 13:453-461.

13. Hübner S, Dejager L, Libert C, Tuckermann JP. The glucocorticoid receptor in inflammatory processes: transrepression is not enough. Biol Chem. 2015; 396:1223-1231.

14. Tuckermann JP, Kleiman A, Moriggl R, Spanbroek R, Neumann A, Illing A, Clausen BE, Stride B, Förster I, Habenicht AJ, Reichardt HM, Tronche F, Schmid W, et al. Macrophages and neutrophils are the targets for immune suppression by glucocorticoids in contact allergy. J Clin Invest. 2007; 117:1381-1390.

15. Reichardt HM, Kaestner KH, Tuckermann J, Kretz O, Wessely O, Bock R, Gass P, Schmid W, Herrlich P, Angel P, Schütz G. DNA binding of the glucocorticoid receptor is not essential for survival. Cell. 1998; 93:531-541.

16. Baschant U, Frappart L, Rauchhaus U, Bruns L, Reichardt HM, Kamradt T, Brauer R, Tuckermann JP. Glucocorticoid therapy of antigen-induced arthritis depends on the dimerized glucocorticoid receptor in T cells. Proc Natl Acad Sci USA. 2011; 108:19317-19322.

17. Kleiman A, Hübner S, Rodriguez Parkitna JM, Neumann A, Hofer S, Weigand MA, Bauer M, Schmid W, Schütz G, Libert C, Reichardt HM, Tuckermann JP. Glucocorticoid receptor dimerization is required for survival in septic shock via suppression of interleukin-1 in macrophages. FASEB J. 2012; 26:722-729.

18. Vettorazzi S, Bode C, Dejager L, Frappart L, Shelest E, Klassen C, Tasdogan A, Reichardt HM, Libert C, Schneider M, Weih F, Uhlenhaut NH, David JP, et al. Glucocorticoids limit acute lung inflammation in concert with inflammatory stimuli by induction of SphK1. Nat Commun. 2015; 6:7796.

19. Wüst S, van den Brandt J, Tischner D, Kleiman A, Tuckermann JP, Gold R, Lühder F, Reichardt HM. Peripheral $\mathrm{T}$ cells are the therapeutic targets of glucocorticoids in experimental autoimmune encephalomyelitis. J Immunol. 2008; 180:8434-8443.

20. Klaßen C, Karabinskaya A, Dejager L, Vettorazzi S, Van Moorleghem J, Lühder F, Meijsing SH, Tuckermann JP, Bohnenberger H, Libert C, Reichardt HM. Airway
Epithelial Cells Are Crucial Targets of Glucocorticoids in a Mouse Model of Allergic Asthma. J Immunol. 2017; 199:48-61.

21. Boieri M, Shah P, Dressel R, Inngjerdingen M. The Role of Animal Models in the Study of Hematopoietic Stem Cell Transplantation and GvHD: A Historical Overview. Front Immunol. 2016; 7:333.

22. Bouazzaoui A, Spacenko E, Mueller G, Huber E, Schubert T, Holler E, Andreesen R, Hildebrandt GC. Steroid treatment alters adhesion molecule and chemokine expression in experimental acute graft-vs.-host disease of the intestinal tract. Exp Hematol. 2011; 39:238-249 e231.

23. Menger L, Gouble A, Marzolini MA, Pachnio A, Bergerhoff K, Henry JY, Smith J, Pule M, Moss P, Riddell SR, Quezada SA, Peggs KS. TALEN-mediated genetic inactivation of the glucocorticoid receptor in cytomegalovirus-specific T cells. Blood. 2015; 126:2781-2789.

24. Theiss-Suennemann J, Jörß K, Messmann JJ, Reichardt SD, Montes-Cobos E, Lühder F, Tuckermann JP, Wolff HA, Dressel R, Gröne HJ, Strauss G, Reichardt HM. Glucocorticoids attenuate acute graft-versus-host disease by suppressing the cytotoxic capacity of CD8(+) T cells. J Pathol. 2015; 235:646-655.

25. Cole TJ, Blendy JA, Monaghan AP, Krieglstein K, Schmid W, Aguzzi A, Fantuzzi G, Hummler E, Unsicker K, Schütz G. Targeted disruption of the glucocorticoid receptor gene blocks adrenergic chromaffin cell development and severely retards lung maturation. Genes Dev. 1995; 9:1608-1621.

26. Frijters R, Fleuren W, Toonen EJ, Tuckermann JP, Reichardt HM, van der Maaden $H$, van Elsas A, van Lierop MJ, Dokter W, de Vlieg J, Alkema W. Prednisoloneinduced differential gene expression in mouse liver carrying wild type or a dimerization-defective glucocorticoid receptor. BMC Genomics. 2010; 11:359.

27. Tischner D, Theiss J, Karabinskaya A, van den Brandt J, Reichardt SD, Karow U, Herold MJ, Lühder F, Utermöhlen O, Reichardt HM. Acid sphingomyelinase is required for protection of effector memory $\mathrm{T}$ cells against glucocorticoid-induced cell death. J Immunol. 2011; 187:4509-4516.

28. Chen X, Das R, Komorowski R, Beres A, Hessner MJ, Mihara M, Drobyski WR. Blockade of interleukin-6 signaling augments regulatory T-cell reconstitution and attenuates the severity of graft-versus-host disease. Blood. 2009; 114:891-900.

29. Tawara I, Koyama M, Liu C, Toubai T, Thomas D, Evers R, Chockley P, Nieves E, Sun Y, Lowler KP, Malter C, Nishimoto N, Hill GR, et al. Interleukin-6 modulates graftversus-host responses after experimental allogeneic bone marrow transplantation. Clin Cancer Res. 2011; 17:77-88.

30. Haniffa M, Ginhoux F, Wang XN, Bigley V, Abel M, Dimmick I, Bullock S, Grisotto M, Booth T, Taub P, Hilkens C, Merad M, Collin M. Differential rates of replacement of human dermal dendritic cells and 
macrophages during hematopoietic stem cell transplantation. J Exp Med. 2009; 206:371-385.

31. Tuckermann JP, Kleiman A, McPherson KG, Reichardt HM. Molecular mechanisms of glucocorticoids in the control of inflammation and lymphocyte apoptosis. Crit Rev Clin Lab Sci. 2005; 42:71-104.

32. Vandevyver S, Dejager L, Van Bogaert T, Kleyman A, Liu Y, Tuckermann J, Libert C. Glucocorticoid receptor dimerization induces MKP1 to protect against TNF-induced inflammation. J Clin Invest. 2012; 122:2130-2140.

33. Gijbels K, Brocke S, Abrams JS, Steinman L. Administration of neutralizing antibodies to interleukin-6 (IL-6) reduces experimental autoimmune encephalomyelitis and is associated with elevated levels of IL-6 bioactivity in central nervous system and circulation. Mol Med. 1995; $1: 795-805$.

34. Korngold R, Marini JC, de Baca ME, Murphy GF, GilesKomar J. Role of tumor necrosis factor-alpha in graftversus-host disease and graft-versus-leukemia responses. Biol Blood Marrow Transplant. 2003; 9:292-303.

35. Sleight BS, Chan KW, Braun TM, Serrano A, Gilman AL. Infliximab for GVHD therapy in children. Bone Marrow Transplant. 2007; 40:473-480.

36. Wang H, Asavaroengchai W, Yeap BY, Wang MG, Wang S, Sykes M, Yang YG. Paradoxical effects of IFN-gamma in graftversus-host disease reflect promotion of lymphohematopoietic graft-versus-host reactions and inhibition of epithelial tissue injury. Blood. 2009; 113:3612-3619.

37. Yang YG, Wang H, Asavaroengchai W, Dey BR. Role of Interferon-gamma in GVHD and GVL. Cell Mol Immunol. 2005; 2:323-329.

38. Beilhack A, Schulz S, Baker J, Beilhack GF, Wieland CB, Herman EI, Baker EM, Cao YA, Contag CH, Negrin RS. In vivo analyses of early events in acute graft-versus-host disease reveal sequential infiltration of T-cell subsets. Blood. 2005; 106:1113-1122.

39. Rose AJ, Herzig S. Metabolic control through glucocorticoid hormones: an update. Mol Cell Endocrinol. 2013; 380:65-78.

40. Lühder F, Reichardt HM. Novel Drug Delivery Systems Tailored for Improved Administration of Glucocorticoids. Int J Mol Sci. 2017; 18:1836.

41. Nishiwaki $S$, Nakayama $T$, Murata $M$, Nishida $T$, Terakura S, Saito S, Kato T, Mizuno H, Imahashi N, Seto A, Ozawa Y, Miyamura K, Ito M, et al. Dexamethasone palmitate ameliorates macrophages-rich graft-versus-host disease by inhibiting macrophage functions. PLoS ONE. 2014; 9:e96252.

42. Kaplan DH, Anderson BE, McNiff JM, Jain D, Shlomchik MJ, Shlomchik WD. Target antigens determine graft-versus-host disease phenotype. J Immunol. 2004; 173:5467-5475. 